\title{
THE AUTHORITY DISPUTE OF STATE INSTITUTIONS IN THE IMPLEMENTATION OF BICAMERAL SYSTEM IN INDONESIA
}

(Study on Disputes between the House of Representatives (Dewanperwakilan Rakyat)-Republic of Indonesia and the House of Representatives-Republic of Indonesia in the Implementation of Legislative Function)

\author{
ABDUL KHOLIK. S. H. M.SI ${ }^{1}$, DEDDY ISMATULLAH. S. H. M.HUM ${ }^{2}$ \& WIDAYATI. S. H. M.H ${ }^{3}$ \\ ${ }^{1,3}$ UNISULA Semarang Central Java, Indonesia \\ ${ }^{2}$ STAI Syamsul Ulum Kota Sukabumi West Java, Indonesia
}

\begin{abstract}
The purpose of this research is, to know the authority dispute of state institution, in applying of bicameral system in Indonesia which is study to dispute DPR-RI with DPR-RI in execution of function of legislation. This research is an analytical description, that is, by collecting data describing or describing facts, and data and analysis from result of the research, which aims to get picture to support law argument systematically and structured, based on normative juridical that is research analysis based on constitution (Indonesian: Undang-undang), also refers to the facts and supporting theories. The approach of research conducted on the problems in this study using sociological juridical approach(Socio-legal study), which means that, in this study conducted an assessment of the rules, norms prevailing in society and research directed to the function of law in society, associated with positive national law, that applies in Indonesia.

The type of research used is empirical law study, and is a legal research method, that seeks to see the law in a real sense and to examine how the law works in society. The authority disputes of state institutions in the application of bicameral system, in Indonesia include: the factors causing the disputes of state institutions in the application of bicameral system, the aspect of the implementation of the legislative function, between DPD-RI and DPR-RI, disputed authority of DPD-RI with DPR- Legislation, dispute resolution mechanisms of state institutions and dispute resolution, results of DPD-RI with Parliament and its impact on the implementation of the legislative function and the steps of reconstruction of state institutions disputes, based on the principles of checks and balances, and the application of bicameral system.

KEYWORD: Disputes, Authority, State Institution, System Implementation and Bicameral
\end{abstract}

Received: Jul 03, 2017; Accepted: Jul 19, 2017; Published: Jul 24, 2017; Paper Id: IJPSLIRAUG20173

\section{INTRODUCTION}

The bicameral system applied in Indonesia, as a result of the constitutional amendment has resulted in the dispute of authority. This inter-state dispute is a new and exciting phenomenon, in the practice of state administration in Indonesia. Practically, the authority dispute has the potential to disrupt the relationship between state institutions in the implementation of their duties and functions.

The amendment is an important milestone of the era of reform, in order to rearrange the life of the nation and state as a whole. Once the significance of the changes is made so that, the constitutional system called experiencing a radical development (JimlyAssiddiqie, 2010: 12), after going through the amendment process, the problems that become the background of the need for change, seem to be answered as reflected in the fundamental changes, in both 
substance and systematic (Dedy Ismatullah, Beni Ahmad Saebani, 2009: 292).

The proposed amendments initially, received a positive response from a number of factions in the House of Representatives (Indonesian: DPR) and the People's Consultative Assembly, of the Republic of Indonesia (Indonesian: MPR). Initially supporting the proposed amendment was finally withdrawn (www.tempo.co.id: May 17, 2007). This is also reinforced by the statement of the Chairman of the House of Representatives - Mr. Marzuki Ali, who requested the constitutional amendment proposal was stopped (www.tempo.co.id: August 30, 2010). In the midst of the failure of the proposed constitutional amendment, the Parliament and the Government drafted and ratified Law No. 27 of 2009 on MPR, DPR, DPD and DPRD (Act of MD3), in lieu of Law Number 22 Year 2003, on the Composition and Position of the People's Consultative Assembly, The People's Representative, the Regional Representatives Council (Indonesian: DPD) and the Regional People's Legislative Assembly (Indonesian: DPRD), followed by the ratification of Law Number 12, Year 2011 on the Establishment of Legislation. Both laws are closely related to the DPD's authority, but in the process the DPD feels uninvolved. For the DPR itself it always holds that, both the material of this bill is not included in the authority of DPD, to participate to discuss, so as not to involve DPD, based on the provisions of Article 22D paragraph (2) of the 1945 Constitution. In response to Law Number 27, Year 2009 and Law Number 12, Year 2011, DPD initially pursued a persuasive diplomatic approach. Through the study of DPD found at least 14 Articles, which contain provisions of things that should be implemented by the House and the DPD. Based on the review, the DPD leadership wrote to the House leadership so that the problem can be solved together. But again did not get adequate response from the House.

Even in the implementation of the legislative function, according to the Regional Representative Council Chairman, Mr.IrmanGusman, there is a neglect of the role of DPD as in the preparation of the National Legislation Program (Indonesian: Program LegislatifNasional). Of the 34 bills proposed by DPD, none were accepted and without explanation from the Parliament. Even against the discussion of the bill that should involve the DPD such as the Population Administration Bill, the Bill on Land Procurement for Development Interest, the DPD is not involved (Rakyat Merdeka Online: 8 September 2012).Development, DPD is not involved (Rakyat Merdeka Online: September 8, 2012). Realizing the failure of a persuasive diplomacy approach, the DPD finally filed a lawsuit / judicial review of Law No. 27 of 2009 to the Constitutional Court (MK). The materials tested include Article 102 paragraph (1); Article 74 paragraph (3) and paragraph (7); Article 102 paragraph (1) and Article 150 paragraph (3). In line with the MD3 Act, is Law Number 12 Year 2011 on the Establishment of Legislation Regulation (UU P3), also regulates the relationship between the DPD and the DPR in the legislation process. In the provisions mentioned DPD "can" involved in the process of drafting the law, which gives the notion of the DPD, is not given the opportunity to participate in the overall process of drafting the Act. According to Todung Mulya Lubis who became the attorney for the DPD, both laws have ignored the constitutional authority of the DPD in the legislation process. Even in the provisions of Article 18 Sub-Article g, Article 20 Paragraph (1), Article 21 Paragraph (1) and Article 23 Paragraph (3), P3 Law is deemed to have excluded the authority of the DPD to be able to submit the Bill either included in the National Legislation Program (Indonesian: Prolegnas), Outside of Prolegnas (www.mahkamahkonstitusi.go.id: 14 September 2012).

Systematic before change consists of three parts: opening, torso and explanation, after change into two parts, namely opening and chapters. In terms of number of chapters, origin, and verse as a whole appears in the details of the amendment results made in four times. Before the change only consisted of 16 chapters 27 Articles, 49 clauses, 4 transitional rule articles and 2 additional rule paragraphs After the change into 21 chapters, 73 articles, 170 verses 3 
transitional rules and 2 additional rule articles. In terms of the substance of the amendment resulted in changes in the position and relationship of some state institutions, the abolition of certain state institutions and the establishment of new state institutions. Overall, the result of the amendment has given birth to 34 organs of state office or institution arranged in the norm of the body of the 1945 Constitution. Some of the state institutions mentioned in the judicial cluster of the new state institutions namely the Judicial Commission and the Constitutional Court. While in the legal family began to apply bicameral system with the presence of new state institutions namely, the Regional Representatives Council, which is the institutionalization of representatives of regional representatives. If traced the idea of formation make this institution as second chamber (second chamber) in representative institutions.

It is clear that there has been a different view of the authority of state institutions between DPD and DPR. These differences of views are accompanied by disputes and claims regarding the powers held by each of the state institutions until they are brought into the hands of a judicial review law in a constitutional court. When looking at the chronology, the dispute is continuous as evidenced by the two lawsuits in the Constitutional Court, and each side continues to defend its views. This is interesting to study because in the perspective of the relationship between state institutions as a new phenomenon since the existence of institutional system of the state of constitutional amendment result.

This research is important to be done considering that there has not been any specifically conducted research in the perspective of authority disputes among state institutions. Various researches on DPD performed more on parliamentary model with two institutions (bicameral) and the problem of applying (Reni Dwi Purnomowati, 2005) or see the strengthening of DPD from institutional perspective in general. These are the reasons behind this research as an attempt to obtain a more comprehensive picture of the dispute between DPD and DPR and how the impact of the dispute on the implementation of legislation functions.

\section{LITERATURE RIVIEW}

\section{Methodology}

This research uses constructive paradigms based on philosophical and methodological aspects that include the ontological, epistemological and axiological dimensions. The type of research used in this dissertation is empirical law research. Is a legal research method that seeks to see the law in a real sense and to examine how the law works in society? Research is analytical descriptive, that is by collecting data describing or describing facts and data and analysis from result of research which aims to get picture to support law argument systematically and structured based on normative juridical that is research analysis based on rule of law Invitations that also refer to supporting facts and theories.

\section{RESULTS AND DISCUSSIONS}

\section{Results}

The authority dispute of state institutions began to emerge since the state administration system changed as a result of the amendment of the 1945 Constitution. One of the fundamental changes occurred in the legislative branch especially related to the formation function of the law. Prior to the amendment of the 1945 Constitution, the power to legislate was still divided between the President and the House of Representatives, then after the amendment of the 1945 Constitution asserted that the power to form legislation was in the DPR.Asamana regulated in Article 20 paragraph (1) of the 1945 Constitution "The People's Legislative Assembly holds the power to form a law (Saidi Isra, 2010: 5)." The provision of Article 5 Paragraph (1) of the original 1945 Constitution (before the amendment) states that "the President 
holds the power to form a law with the approval of the House of Representatives. Meanwhile, in the provision of Article 5 (1) of the 1945 Constitution after the amendment becomes "President shall have the right to submit draft law to the House of Representatives".

The idea of developing a bicameral parliament in Indonesia surfaced at the time of the 1945 Constitution, and had a long debate and there were two views. One side agrees and the other side does not agree with the reason to be able to compete with the existing legislative body. Based on the results of the MPR sessions, initially the idea did not directly lead to the development of bicameral system, but more on how to maintain the existence of the Regional Representatives which originally existed in the DPR. In the next stage, the term "bicameral parliament" appears in the view of factions such as the Golkar faction, the $F B B$ faction, although it is still rejected by the PDIP Fraction which is worried that this institution will rival the House. The result is then the emergence of the Regional Representatives Council which contains elected members through the General Elections to represent the aspirations of the regions. It's just that the final formulation of DPD is placed as an institution whose function is limited to certain authorities who are primarily related to regional autonomy (ValinaSingkaSubekti, Op. Cit). The end result of the different views is as defined in Chapter VIIA, Article 22C and Article 22D of the 1945 Constitution on the Regional Representative Council.

According to the provisions in Article 22D of the 1945 Constitution, DPD has authority, among others, covering:

- Able to propose to the House of Representatives a draft law relating to regional autonomy, central and regional relations, the establishment and area expansion and merging of regions, the management of natural resources and other economic resources;

- To discuss the draft laws relating to regional autonomy, central and regional relations, the establishment and division and merging of regions, the management of natural resources and other economic resources

- Providing consideration to the DPR related to the draft state budget revenues and expenditures; Draft laws relating to taxes, education and religion;

- Can supervise the implementation of laws related to regional autonomy, central and regional relations, the establishment and division and merging of regions, the management of natural resources and other economic resources

\section{DISCUSSIONS}

\section{Definition of Bicameral System}

Systems are rules that are thoroughly and interconnected with each other. In sociology studies called social systems can be interpreted as a set of social roles that interact or social groups that have the same values, norms and ideals (TaufikRahman, 2011: 114).Bicameral such as the Senate and the House of Representatives in the United States a bicameral legislature United States politics and government (Elizabeth Walter, 2008: Version 3.0).

A bicameral legislature is one in which the legislators are divided into two separate assemblies, chambers or houses. Bicameralism is distinguished from unicameralism, in which all of the members deliberate and vote as a single group, and from some legislatures which have three or more separate assemblies, chambers or houses. As of 2015, somewhat less than half of the world's national legislatures are bicameral. (https://en.wikipedia.org/wiki/Bicameralism). 
Thus bicameral system is a rule that is thoroughly and interrelated between each other on state institutions into two parts of which is in the family of judiciary born a new state institution namely the Judicial Commission and the Constitutional Court. While in the legal family began to apply bicameral system with the presence of new state institutions namely, the Regional Representatives Council, which is the institutionalization of representatives of regional representatives.

\section{Review of Legal Theory}

Aristotle (George H. Sabine, 1961) says that the best life can be achieved by the supremacy of the law. Law is the collective wisdom of the citizen (Jimly Assiddiqie, 2009). Implementation of the government until the end of the new order is not able to present a democratic government so that reform occurs with the main agenda is the structuring of state administration implemented through the amendment of the 1945 Constitution (ValinaSingkaSubekti, 2008: 19). Imanuel Kant, which the state equated with the night watchman (nachwakestaate) This means that the state only acts to strike with its wand, if peace, order, and security or private rights are threatened. In this conception the task of the state is to maintain security and order only (Sudargo Gautama, 1983).

The formal legal state refers to the country in which its government and all its branches of government are subject to the applicable law. While the legal state of the material refers to a state based on law, but not limited to formal laws alone, but a just law that prosper the community. MunirFuadi (2009: 27), in the development of the concept of a material legal state is in line with the principle of welfare state (welfare state). In view of A.V. Dicey there are three important features in The Rule of Law "which includes three things: (A. V. Dicey, 1959): (1). Supremacy of law, (2) Equality before the law, (3) Due Process of law

As in the conception of the state of Islamic law, based on Ibn Khaldun's thought, as dictated by S Ahmad W Husaini, that there are two human conditions namely the condition of nature and the condition of civilization the conception of a legal state is in a second, credible human condition. Menrurut Ibn Khaldun in the mulksiyasi there are two forms of legal state that is (M. Tahir Azhari, 2003: 13);

- Siyasah diniyah which is defined as Islam nomocracy. In this conception the law is a product derived from revelation (shari'ah) and the law which is the result of the work of human reason. Both are laws that are in the state with the principles of Islamic nomocracy.

- Siyasah aqliyah is also called secular nomocracy. The law that applies here is solely the result of human thought.

Islamic law states (nomocracies) have general principles that include

- The principle of power as a mandate, that the formulation of power in nomocracy Islam is a gift of God which is a mandate to be nurtured and carried out properly in accordance with the principles established in the Qur'an and exemplified in the Sunnah of the Prophet. Each of these powers will ultimately be accounted to God (M Daul Ali, M. Thahir Azhary).

- The Principle of Deliberation, according to Hasan Ibrahim, as quoted by Sarja, the outline of the deliberation of statehood can be divided into three categories. First, deliberations in the election of the head of state (khalifah) asamana in the election of the caliph after the death of the Prophet. Second, the deliberations in the formation of the Constitution, as performed by the Prophet when forming the Medina Charter. Third, deliberation in terms of 
security and war, as exemplified in the war Tabuk (Sarja, 2016: 37).

- The principle of justice, the principle of justice there is provision in the QS. Al An'am verse 152 and QS. Al Maidah verse 8. The principle of justice in the context of Islamic nomocracy, it is seen in terms of the function of state power which includes three main functions. First, the obligation to apply power fairly, honestly and wisely so that all people can feel justice without exception. Second, the duty of applying judicial power to the utmost fair, so that the law applies to all regardless of one's position. Third, the obligation of state administration to create justice and prosperity (principle of social justice) (M. Tahir Azhary, Op.Cit: 119).

- The principle of equality, equality in nomocracy covers a wide range of political, legal, economic and economic. Etc. In the field of law, for example, applied by the prophet when asserting "By Allah, if Fatimah my daughter steals will still cut her hand (Op.Cit: 126).

- The principle of recognition and protection of human rights, in the view of Islam, is the obligation of the state and government to protect all its people, and has been implied both in the time of the prophet and of the caliphate (Sarja, Op.Cit: 49).

- The principle of free trial, in the teachings of Islam, the judge must decide the case with the fairness and freedom from the pressure of any party. The reference is QS. An-Nisaa verse 5 and also the hadith of the Prophet which means "If a judge pursues law (honestly) and his decision is true, then he will get two rewards. But if the decision is wrong then he will get one reward. (Narrated by Al-Bukhari).

- The principle of Peace, hostility / war is essentially prohibited. War is only an emergency measure and defensive in self-defense. If the war was to be done the Prophet gave the rules of law of war as prohibited from killing the musush beyond the limits of humanity, forbidden to kill civilians, women, children, parents etc., forbidden to kill prisoners of war, forbidden to persecute prisoners of war, Azhary, Op.Cit: 148).

- The principle of welfare, the principle of welfare in Islam, in accordance with the doctrine of the balance of the relationship with God and the relationship with man (hablun min Allah wa hablun min al-nas) (Op.Cit: 152).

- The principle of people's obedience, this principle relates to the relationship between the people and the government (leaders) outlined in the QS. An-Nisaa verse 59 which means "Hi, you who believe, obey Allah and obey His Messenger and the authorities among you. If you differ on a matter, then return it to Allah (Qur'an) and His Messenger (Sunnah) if you truly believe in Allah and the Last Day. That is more important to you and better consequences.

The view of the Pancasila legal state was stated by Oemar Senoaji, that for the Indonesian nation Pancasila is the source of all sources of law, it is called Pancasila state law. The main characteristic is the guarantee of freedom of religion, which is interpreted positively so that in Indonesia is not known by the name of atheism or anti-religious propaganda. This is what distinguishes the concept of the legal state of both Continental Europe and common law countries in the guarantee of freedom of the individual (HAM) more loosely related issues of religious rights (Oemar Seno Aji, 2003). In more depth, PadmoWahyono, describes the notion of a Pancasila legal state based on the principle of kinship as stated in Article 33 of the 1945 Constitution before the amendment.

The principle contained in this principle is the interests of the people, but human dignity and prestige are 
respected. This principle also affirms that the priority is the prosperity of society and not the prosperity of one's people, one's business is guaranteed as long as it does not disturb the life of the people (PadmoWahyono, 2003). The law in Indonesia is symbolized by a tree of "pengayoman" that contains the meaning of law must protect all people / all groups. This tree symbol is used by Ministry of Law and Human Rights as a form of developed law and the behavior of law enforcement in Indonesia is nurturing.

The concept of legal state continues to grow along with the development of the era and democracy in various countries. The development of the concept of a state of law has implications for its elements and characteristics. Based on the various views of experts, JimlyAssiddiqui (Jimly, Op.Cit) identifies the existence of twelve principles as pillars that support the legal state:

- The supremacy of law

- Equality before the law.

- The principle of legality

- Restrictions on power

- Independent state organs.

- A free and impartial judiciary.

- State Administrative Court.

- The Constitutional Court.

- Protection of human rights.

- Democratic.

- Serves as a means of realizing the goals of the state.

- Transparency and social control.

Another opinion similar to Jimly with reference to various opinions of experts on the characteristics of the legal state both in the perspective of Continental European countries and Anglo Saxson, Munir Fuady (MunirFuady, Op.Cit) also concluded a number of important elements that must exist in a legal country as follows:

- State power is not absolute.

- Equal treatment of citizens before the law

- The application of the principles of trias politica (The separation of powers).

- The application of checks and balances system.

- The mechanism of institutional implementation of a democratic state.

- $\quad$ The free judiciary.

- An orderly legal system under the constitution. 
- Protection of human rights.

- The testing mechanism of the legislative, executive and judicial products against the constitution.

- The fair and objective impeachment process.

- Fair, efficient, rational and transparent trial process.

- The existence of press freedom.

- Governance according to the principle of good governance.

- Implementation of the principle of majority rule protection minority.

- Citizen participation in selecting state officials in the executive, legislative and judicial sectors is limited.

The principles of the above legal state continue to grow associated with the growing strength of the sovereignty of the people and democracy in the life of the state. As specified in the International of Commission of Jurist (ICJ) establishes minimum standards of legal state elements (Azhary, 1995):

- Personal security must be guaranteed.

- No fundamental rights can be interpreted, such as allowing a country's equipment area to issue a regulation to take action on fundamental rights.

- A review of freedom of expression.

- $\quad$ Personal life is not violated.

- Religious freedom must be guaranteed.

- Right to receive instruction.

- $\quad$ Right to assemble and union.

- A free and impartial judiciary.

- Freedom of choice and election in politics.

In the practice, despite the separation of powers between the branches of the legislative, executive and judicial powers, it can not necessarily produce a balanced format. Often there are heavy legislative conditions or otherwise executive heavy conditions. Therefore, it is necessary for the theory of checks and balances to complement the refinement of power separation / power sharing. One of the practical reasons for this theory is the fact that humans as organizers are not angels, so the tendency to extend power / authority often occurs. In implementing the principle of checks and balances is done through the following mechanism (Munir Fuadi, Op.Cit: 124):

- The granting of authority to an action to more than a branch of power in government. For example, the authority of legislation granted to the government and parliament together. This means that there is a legal overlapping of the authority of state officials between one branch of government with other branches of government.

- Provision of authority to appoint state officials to more than one branch of government both executive and legislative. The mechanism can be through the proposing executive then the legislative who chooses and 
establishes.

- Efforts impeachment of the branch of government against other branches of government.

- Direct supervision of the branch of government against other branches of government. Such as executive oversight by the legislature in the execution of the budget or other policies.

- The granting of authority to the court as the final word in the event of a dispute over authority between branches of state power / institution.

Thus the principle of checks and balances is important in the relationship between state institutions. According to James L Sundquis, as quoted by A. RoshidAtok that through checks and balances every branch of state power is overseen by other branches of power This is in accordance with the position among the state institutions are equal and mutually supervising. This principle also directs the absence of kebutuan in the implementation of the functions of state institutions or abuse of authority due to absolute power (A. Rosyid Al Atok, 2015).

Hans Kelsen (1961) mentions that state organs / institutions are only associated with public offices and officials / public officials in the organic state office. Based on the opinion of Kelsen, in more detail JimlyAssiddiqie, describes the meaning of the organs The term organ of the state in various literatures equated with the term state institution, but sometimes in the use of everyday terms also other mention of government institutions, non-departmental government institutions or state institutions Only. State in five terms (JimlyAssiddiqie, Development and Consolidation of State Institutions Post Reform, Op.Cit):

- Includes any individual performing the function of establishing and enforcing the law.

- Includes individuals who perform the function of establishing and enforcing laws and also having positions as or in the structure of the state or government office.

- The bodies or organizations that perform the function of establishing and implementing legislation within the framework of the structure and system of state or government.

- The organs or state institutions established under the Constitution or established under lower laws and regulations.

- Organ / state institutions whose establishment is regulated in the Constitution and its position at the central level. In the context of Indonesia which is referred to this category adalam state high institutions that exist in the 1945 Constitution.

Furthermore, according to Jimly, to better recognize the characteristics of state institutions can be seen from two interrelated aspects of organ and function. The organ referred to here is the shape or container, while the function is the content. Also understood the organ is the status of its form and function is the movement according to the purpose of its formation. In terms of function there are two categories namely (Ibid):

\section{State Main Institution / Primary (Primary Constitutional Organ)}

The main state institution is the embodiment of three branches of state power: the executive, the legislature and the judiciary. This category of state institutions can be seen in each branch of the power such as the executive branch, for example, the President is the main institution while the assistant / minister do not enter this type. Similarly, in the 
legislative branches of the main state institutions are the House of Representatives (DPR), and on the branch of the judiciary the main state institutions are the Supreme Court and the Constitutional Court (MA) Constitution (MK).

\section{Institutions of the State of the Supporting Organs (auxiliary state organs)}

This type of institution is also linked to the branch of state power but in a position to support the function of other institutions. The Minister becomes a supporting state institution for the President and Vice President. Although not accurate, in terms of function DPD can be called as a supporting state institution for the House of Representatives, because its function is more giving advice and consideration to the House. Similarly, the Judicial Commission becomes a supporting state institution for the Supreme Court (MA) in the implementation of the function of the judicial branch, especially related to the recruitment and supervision of judges.

In addition to the categorization based on the position and function of state institutions as described above, when viewed from the aspect of its formation, state institutions can be distinguished in the categories of first, second, and thirdtier state institutions as follows:

- The First Layer State Institution, the first layer is an institution established directly in the constitution (the 1945 Constitution). Including this category if the state institutions formed and obtain the authority of the 1945 Constitution. In other terms and for the sake of ease of understanding this institution is also called a state high institution. State institutions including the first-line institutions, namely the President and Vice President, the People's Consultative Assembly (Majelis Permusyawaratan Rakyat), the House of Representatives (Indonesian: Dewan Perwakilan Rakyat), the Regional Representative Council (Dewan Perwakilan Daerah), the Supreme Court (Mahkamah Agung), the Constitutional Court (Mahkamah Konstitusi), the Supreme Audit Board (Bandan Pemeriksa Keuangan).

- The Second Layer State Institution, a second-tier State institution, is an institution which is authorized by the 1945 Constitution and some of it is authorized by law. State institutions that fall into the second tier category are the State Minister, the Indonesian National Army, the State Police, the Judicial Commission, the General Election Commission and the Central Bank

- Third-State Agencies, state-owned institutions where they are established and obtain the authority only under legislation under the law. Some of the institutions that fall into this category are the National Law Commission (Komisi Hukum Nasional), the National Agency for Combating Terrorism (Badan Nasional Pemberantasan Terorisme) and the National Amil Zakat Agency (Badan Amil Zakat Nasional).

Based on the above description it appears that the structure, position of state institutions undergo fundamental changes in both institutional structures and their duties and functions and authorities. One of the fundamental changes occurred in legislative branches, especially those related to the implementation of the legislative function. Prior to the amendment of the 1945 Constitution, the power to form legislation was still divided between the President and the House of Representatives, the provisions of Article 5 Paragraph (1) of the original 1945 Constitution (before the amendment) stated that "the President holds the power of forming the law with the approval of the House of Representatives. Meanwhile, in the provision of Article 5 (1) of the 1945 Constitution after the amendment becomes "President shall have the right to submit draft law to the House of Representatives", after the amendment of the 1945 Constitution stipulates that the power to form law is in the DPR. As stipulated in Article 20 paragraph (1) of the 1945 Constitution which reads "the 
People's Legislative Assembly holds the power to form laws."

The shift of power to form legislation by Parliament was also accompanied by the establishment of the Regional Representative Council. The formation of the Regional Representative Council is to institutionalize the representation of regional delegates and group delegates originally existing in the the People's Consultative Assembly, where the electoral mechanism was initially appointed and in the later stages selected by the Provincial DPRD to represent regional interests. Which together with the house are included in the legislative family. The underlying reason for establishing this institution is in the perspective of the implementation of the Legislation function in the view of constitutional law experts as a "double checks" system which enables each legislation product to be double-checked so as to ensure aspiration and in the aspirations of regional interests. The requirement of membership of these two parliamentary chambers must really represent the interests of the different from each other, so that it really reflects the whole people. DPD represents the people in the orientation of interests associated with regionalism, while the DPR represents the people in general within the sphere of national interest embodied in the process of legislation (JimlyAssiddiqui, 2005).

The position and function of law in a constitutional state is more strategic whether viewed from the conception of the state law itself as well as seen from the function of law in general. In the state conception of law is one form of legal norms formulation in the life of a country. As revealed in Paul Scholten's opinion, that law is in the legislation so that everyone should give it a high place (SaciptoRahrjo, 2006).

Same with Scholten, Bagir Manan, also explains that the existence of legislation and legislative activities have a more important and strategic role as the main supporter in governance of Bagir Manan government, 1992). Some of the underlying reasons are:

- Legislation is a rule of law that is easily recognizable (identifiable), easy to rediscover and easy to trace. As the rule of law is written, the form, the type and precisely obvious as well as the maker (the establishment body).

- Legislation provides more real certainty because its rules are easily identifiable and easily recoverable.

- The structure and systematics of the legislation are clearer allows for review and tested both in terms of formal and material.

- The establishment and development of legislation can be planned. This is very important for countries that are building a new legal system according to the needs of society.

The significance of the law can also be seen in the context of its position as the norm which becomes the constitutional derivative (basic norm). This can be seen in the view of the German jurist Hans Nawiasky in his famous book Theorie von Stufernordnung der Rechtnormen, which the laws of his position are in the midst of a bridge between the constitution (basic rules / rules) and the rules of the implementer and the rules of autonomy. This is due to the content of constitutional content as the basic rule / principle in principle is very limited to the basic and basic things, so to implement it must be formulated in clear and detailed general rules in the form of law and then newly described more technical and Detailed in implementing rules (Rosyid al Athok, Op.Cit: 3). Herein lies the importance of the existence of the law as a further elaboration of the Constitution.

Because of the strategic and importance of the status of the law in the life of the state, each country will always regulate the formulation of the law through a good process. The process includes the stages of planning, drafting, 
discussion, approval and endorsement. Law Number 12 Year 2011 on the Establishment of Laws and Regulations. It includes efforts to establish checks and balances mechanisms between state institutions involved in the legislative process, either through the cooperation of state institutions included in legislative clusters, as well as with the executive agencies as those who are also involved in the legislative process. This is in accordance with the principles of division / separation of power in which it contains aspects of relations and cooperation between agencies / state institutions.

Conflict theory is needed to explain why and how disputes occur. Of the several conflict theories that further explain the conflict in the context of group conflict in accordance with the framework of this research is the theory of conflict structuralism developed by Leweis A Coser and Raflf Dahrend of and George Simmel.

According to Cosser, conflict is not always negative, but has a positive meaning because it can contribute to maintaining social structure. Conversely, if the conflict occurs negatively it will weaken the community. Because conflicts with other groups can reinforce group identity, heighten group solidarity and protect groups. According to Cosser, there are two types of conflict that are realistic and unrealistic. Realistic conflict comes from disillusionment with the special demands that occur in the relationship and the expected likelihood of its benefit to an object that does not match expectations. While unrealistic conflicts are not derived from antagonistic competition objectives but rather the need to ease tensions between one party (Margaret M. Poloma, 2003: 128).

In principle Coser believes that conflicts will be dysfunctional for a social structure if there are not enough tolerance or conflict institutionalization mechanisms that threaten "destruction" that disrupts social agreements due to structural rigidity (no conflict channels). Things that threaten the balance of structure if the existing stiffness let the conflict grow accumulated and when it explodes will cause division.

The next conflict theory still in the group Structuralism of the conflict is the view of Ralf Dahrendorf. That in any association characterized by opposition there is tension among those involved in the power structure. The clash of groups can be seen as a contradiction of the legitimacy of power relations. In his view the nature of conflict can be either vertical or horizontal (Ibid: 129).

From the perspective of sociologists the structuralism group can provide perspective to see the conflict between the Regional Representative Council and the House of Representatives, both among actors and institutional. The sociological perspective from the point of view of conflict theory can enrich the dispute analysis of the authority of state institutions.

The theory relating to parliament, actually still has a relationship with the conception of the rule of law, especially the separation of power / power-sharing. In general, in the implementation of separation of power, consisting of executive, legislative and judicial power Parliament is the embodiment of a branch of legislative power whose existence in a democratic state is increasingly important, since it is a form of people's representation elected directly through elections. Parliament of the functions as the establishment of laws and supervise the government as well as channel the aspirations and interests of the people aggregation.

Theoretical discussion of the structure of parliament seen from the number of existing rooms so that leads to two forms of parliament are:

\section{Unicameral System}


This system is a one-room parliament, which means there is only one representative body. Excess system is certainly simpler and avoids the possibility of congestion or "deadlock" in discussing a problem because there is no other room. In practice this system is more widely used (popular) in most countries in the world, especially countries that are unitary. Countries in the world that use and especially in Asia such as Japan, Singapore, Vietnam, Kuwait, Malaysia and the others

\section{Bicameral System}

This system was originally widely used by the state with the federalist system, but in its development also adopted by the unitary state. In reality, the division of parliament into the Lower House and the Upper House, as applicable in England is known as Lord House. In the United States are known two institutions namely the Senate and Congress. The country that uses this system is Malaysia which calls it the State Council, while in Germany it is called the Bundesrat. While in France, Australia, and Canada is called Senate (Reny DWI Purnomo, Op.Cit: 15).

When explored the reason for selecting and applying a bicameral system is to establish a mechanism of supervision and balance of checks and balances as well as for a double check of a legislation product. Another reason is to ensure the representation of different groups that may not have been represented by the first agency.

According to Andrew S. Elis, the bicameral system can be classified into two forms of "strong" (strong bicameral) and the "soft" (soft bicameral). In a strong bicameral system, legislation begins with any assembly and should be considered / discussed by the same forum before it is ratified. Whereas in "the soft" systems one assembly has a higher status than the other. This is the case in the case of the authority of one council stronger than the other (Reny Dwi Purnomo, Loc.Cit: 23).

Parliamentary forms of unicameral and bicameral will have an impact on the mechanism of legislation (legislation). In fact, however, the formation of laws in bicameral and unicameral parliaments in different countries is different from each other. In practice the main provisions concerning the process of formation, including the authority of state institutions in the process of forming the law are regulated in the constitution of each country (Rosyid Al Atok, Op.Cit: 7).

The theory of parliament is needed to complement the discussion regarding the implementation of legislative functions in the parliamentary system using a unicameral or bicameral model. Some of the leading experts in this theory include Lord Bryce, John Stuart Mill and Jimly Assiddiqui. The principle of checks and balances in the formation of laws is also created in the mechanisms and patterns of relationships between state institutions that perform legislative functions. The relationship pattern of state institutions in parliament is what impacts on the existence of the theory of parliament that leads to two main models of unicameral system and bicameral system.

\section{The Dispute Authority of State Institutions in the Implementation of Bicameral System in Indonesia}

The existence of the DPD is constitutionally juridical already final, although it later raises criticism related to the limited authority so that the initial idea of developing a bicameral parliament becomes floating. In view (Jimly, Op.Cit: 121), the DPD's power in the field of legislation is not entirely. More properly referred to as co-legislator in addition to the House of Representatives the nature of the task and authority more to the position as auxiliary body for the implementation 
of legislative tasks of the House

In the process of forming the law, the Regional Representative Council has no authority to take decisions when the draft law is discussed. Despite the fact that the position and authority of the Regional Representative Council legislation is weak but as long as it is regulated and determined in the constitution, the state institution actually has its constitutional foundation. It is important to emphasize the existence of such circumstances that lead to conflict of law (Legal dispute) or the occurrence of constitutional authority disputes with other state institutions.

Although ideally the dispute over the authority of state institutions is not always expected to occur in the form of state agency relations, but the law always strives to provide space / channel when the problem arises. This is important to ensure that there is no deadlock in the implementation of its function. It is in this context that it becomes important to look at the dispute over the authority of the state institutions, the settlement mechanisms and their impacts.

As a new phenomenon in the dynamics of inter-state relations of authority disputes, there is still little discussion of the authority disputes theory. According to Jimly, the definition of dispute over the authority of state institutions is the disagreement with the dispute and claim on the authority possessed by each state institution with other state institutions concerning the authority possessed by each state institution (JimlyAssiddiqie, 2006).

From the definition of authority disputes mentioned above there are two main elements that must be met namely:

- The existence of constitutional authority as determined in the Constitution.

- The incidence of disputes in the exercise of such constitutional authority as a result of differences in interpretation between two or more related state institutions.

- The factors causing the disputes of state institutions include several matters which include (Ibid):

- In the constitutional system regulated in the 1945 Constitution after the amendment, the mechanism of inter-state relations is horizontal, no longer vertical. With such a horizontal relationship pattern then there is no longer the highest state institution. The state institution is only a state institution. Thus before the People's Consultative Assembly as the highest state institution, now equal to each other.

- The pattern of relations between state institutions is balances and checks, where state institutions are recognized equally and mutually controlling / balancing each other. Consequently in exercising the authority of each state institution there are differences and disputes in interpreting the provisions of the 1945 Constitution which regulates its authority.

- The norms that determine the authority of subjects set forth in the 1945 Constitution, are not only related to the constitutional subjects commonly known so far in the execution of duties and functions of state institutions, but also related to the subject of broader authority. If the state institutions are impeded in exercising their respective constitutional powers, it may raise a dispute of authority to be resolved.

In the case of the implementation of the legislative function (the formation of law) there is also a dispute, especially related to the implementation of the authority of the Regional Representative Council of the Republic of Indonesia (Dewan Perwakilan Daerah) and the House of Representatives of the Republic of Indonesia (Dewan Perwakilan Rakyat). Under the provisions of Article 22D of the 1945 Constitution, the Dewan Perwakilan Daerah has the authority to 
file and contribute to the draft laws relating to regional autonomy, central to regional relations, the establishment of regional divisions and mergers, the management of natural resources and other economies as well as On regional financial problems, taxes, education and religion (Formulation of Article 22D Paragraph (2) of the 1945 Constitution).

In practice, the authority is felt very weak by members of the DewanPerwakilan Daerah, because the form of involvement is very limited and has no right to participate in determining the approval / decision making and does not have the space to engage in the discussion of a bill with the Parliament. This is reflected in Law Number 22 Year 2003 on the Composition and Status of the People's Consultative Assembly, the People's Legislative Assembly, the Regional Representative Council and the Regional People's Procurement Council which tend to manage the three institutions in separate legislative assemblies (MPR, DPR and DPD). In the development of Law No. 22 of 2003 revised into Law No. 27 of 2009 and then revised back into Law No. 17 of 2014. As a result not regulated how Dewan Perwakilan Daerah mechanism in proposing the bill, involved in discussing the Bill with the Government and Parliament, or mechanism if Dewan Perwakilan Daerah is not agrees to a bill already agreed by the Parliament and the Government.

Faced with such conditions, in 2005, the leadership and all members of the Regional Representative Council proposed amendments to the Constitution for the strengthening of powers. One of them wants to include a veto in the process of forming the law as the authority of the Regional Representative Council.

The proposals are proposed for the Regional Representative Council to approve or reject the Bill related to regional autonomy, central to regional relations, the establishment of regional divisions and merger, management of natural resources and other economies (SaldiIsra, 2006).

Apart from the subject matter, state agency disputes can also be approached from disputed objects or materials. The object of the dispute is what authority is regulated and determined in the Constitution which is attributed as a function of an organ mentioned in the Constitution, and whether to exercise the authority is hampered or disrupted due to certain decision of state institution.

Furthermore, to handle the disputes of state institutions of the 1945 Constitution has assigned to the Constitutional Court (MK). This can be seen from the provision of Article 24C which reads "The Constitutional Court has the authority to hear at the first and final level whose final decision is to examine the law against the Constitution, to decide the dispute on the authority of the state institution whose authority is granted by the Constitution, to decide Dissolution of political parties and decide disputes over election results."

In the trial lawsuit at the Constitutional Court, there was a long debate and presented a number of state administrators. Similarly, the Parliament and the Government provide information and views from the interests of their respective institutions. In the end the decision of the Constitutional Court to grant the Regional Representative Council lawsuit for some so that the authority of the Regional Representative Council in the implementation of the legislative function is strengthened as contained in the decision of the Court Number 92 / PUU-X / 2012. The verdict was greeted enthusiastically by the leaders and members of the Regional Representative Council and called it an important history especially in the institutional journey of the Regional Representative Council and the institutional system of the state.

Efforts to fight for constitutional authority that has gained strengthening from the Constitutional Court institution, in reality not necessarily the decision can be implemented. The attitude of the People's Legislative Assembly still holds to the old provisions, because although it has been cancelled by the Constitutional Court, has not made new rules as a change 
in accordance with the spirit of the Constitutional Court's decision. The attitude of the House of Representative is again unclear in implementing the Constitutional Court's decision, especially when preparing the amendment / amendment of Law Number 27 Year 2009, which began in 2013 until 2014. The result in August 2014 the House of Representative legitimates the revision of the MD3 Act to Law -The Number 17 of 2014.

The substance of Law No. 17 of 2014 still puts the Regional Representative Council or the DPD in a condition that is more or less the same as Law Number 27 Year 2009. This causes the DPD to re-castrate its authority so that it filed a lawsuit lawsuit number 17 of 2014 to the Court Constitution. In this lawsuit not only the substance aspect concerning 21 Articles weakens the authority of the DPD, but also sues the validity of the forming process (formal aspect) as it assesses the process of its establishment against the provisions of the legislation (www.hukumonline.com: 15 August 2014).

Thus the lawsuit is the second time and still concerns the authority of the DPD which is considered castrated by the Parliament through Law No. 17 of 2014. Moreover, with the birth of the new MD3 Act not only castrate the authority again, but also violate the decision of the Constitutional Court No. 92 / PUU-X / 2012 which has affirmed the authority of the $D P D$ based on constitutional interpretation. The result of the lawsuit again reaffirmed the authority of the $D P D$ in the implementation of the legislative function as contained in Decision Number 79 / PUU-XII / 2014.

The parties to the dispute over the authority of the state institution in technical terms are the applicant and the requested party. The state institution can be an applicant or have legal standing as an applicant are all state institutions whose authority is called and regulated in the Constitution. According to Jimly, a state institution that can be a party either as an applicant or a petitioner in a dispute over the authority of a state institution includes 28 organs / institutions covering (Ibid):

- The President.

- Vice President.

- The Presidential Advisory Council.

- State Ministries.

- Ambassadors.

- Consul.

- Provincial Government.

- Governor.

- Provincial DPRD (Regional People's Representative Assembly)

- The Regional Government of the Regency.

- Regent.

- Regency DPRD.

- Municipal Government.

- The mayor. 
- City Council.

- Majelis Permusyawaratan Rakyat (the People's Consultative Assembly).

- People's Representative Council.

- Regional Representative Council.

- Election Commission.

- The Central Bank.

- Supreme Audit Board.

- Of the Supreme Court.

- Of the Constitutional Court.

- The Judicial Commission.

- Indonesian National Army.

- Police of the Republic of Indonesia.

- Special Regional Government Units.

- Unity of Indigenous People.

However there is an exception that the Supreme Court (MA) cannot be a party to the dispute over the authority of state institutions. As mentioned in Article 65 of Law Number 24 Year 2003. Law Number 8 Year 2011 regarding the Constitutional Court. The provision of Article 65 states that "the Supreme Court cannot be a party to the dispute over the authority of state institutions whose authorities are granted by the 1945 Constitution of the State of the Republic of Indonesia to the Constitutional Court.

In the case of verdict, where the judicial review of the law in the Constitutional Court, so the decision is final and binding (Provision in Article 24C of the 1945 Constitution) There are three possible judgments on the petition for dispute over the authority of state institutions in accordance with the results of the hearing in the hearing namely:

- The application is declared unacceptable (nietontvankelijkverklaard);

- Application rejected; or

- Request granted.

In addition to the possibility of these three decisions, the Constitutional Court pursuant to Article 63 of Law Number 24 of 2003 jo. Of Law Number 8 Year 2011, may issue a stipulation ordering the applicant and / or the requested Party to temporarily suspend the exercise of the disputed authority until a final and binding Constitutional Court decision is reached on the matter disputed. Such a stipulation shall contain an interim order constituting an interlocutor or a provision of a provision which may be issued by the Constitutional Court upon the request of the applicant. 


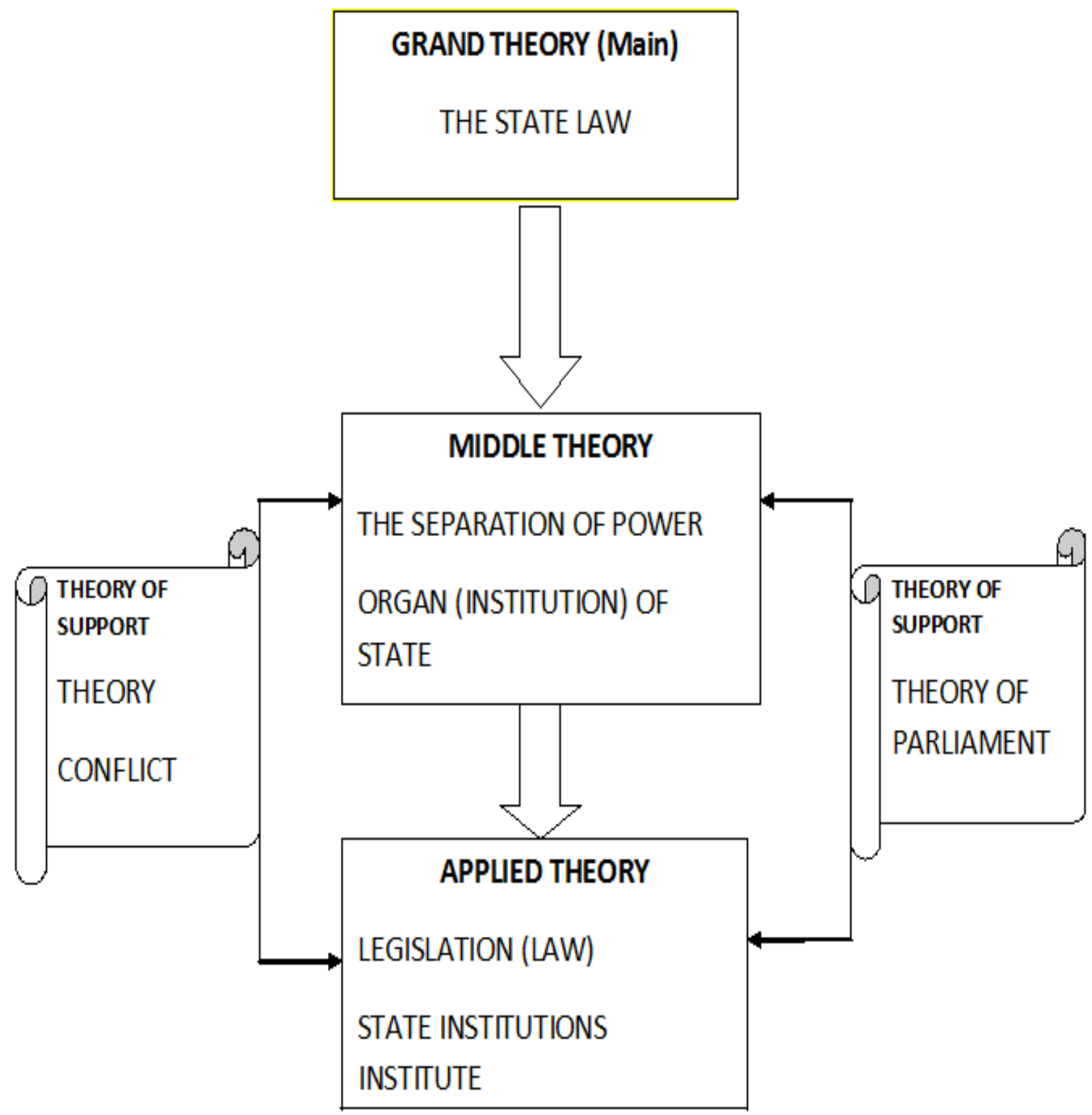

Scheme 1: The Dispute State Institution in Legislation Function (DPD RI vs. DPR RI)

The use of this theory will show the relation in the process of forming the law between the Regional Representative Council $(D P D)$ and $D P R$. 


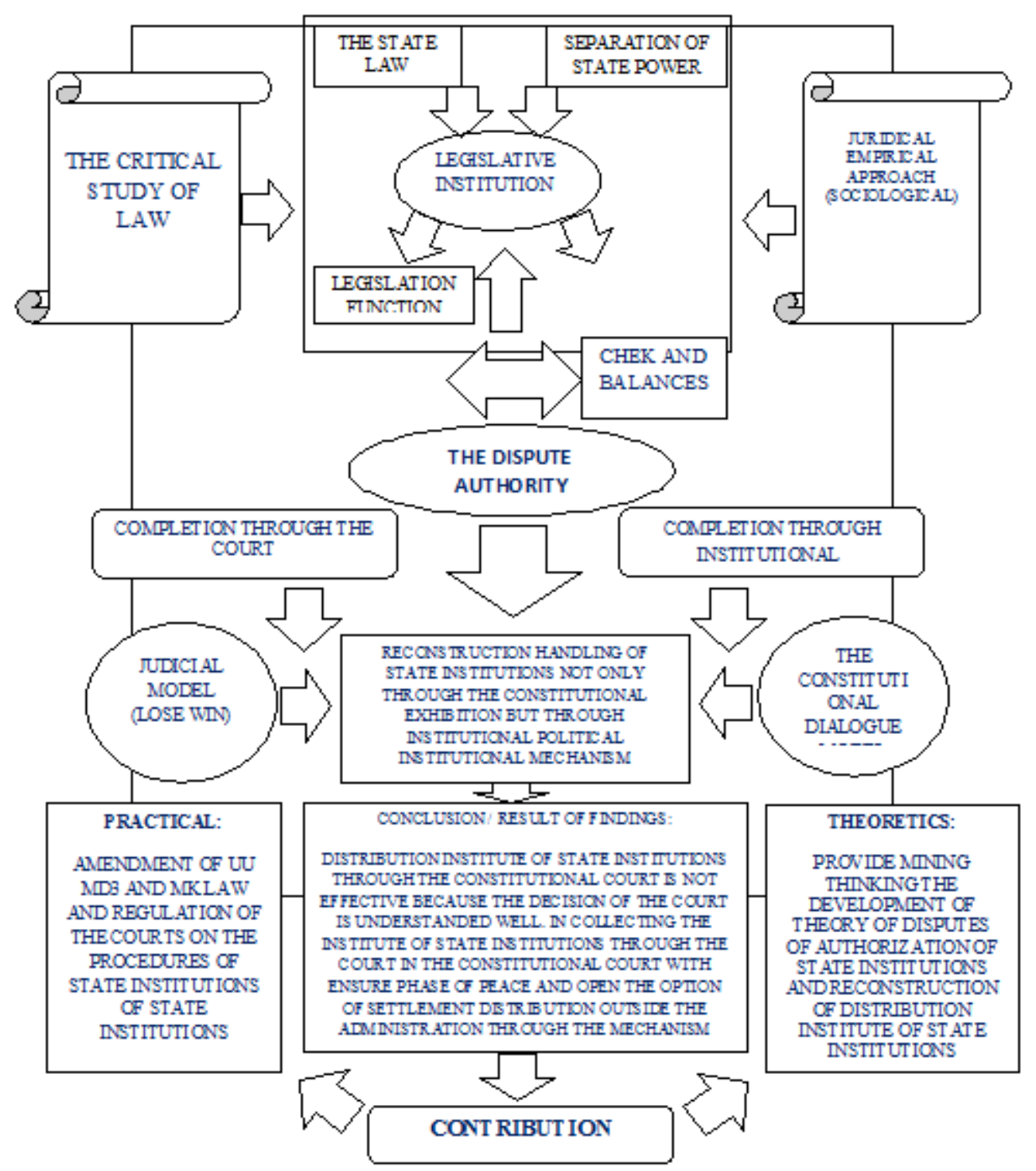

Scheme 2: The Dispute Authority of State Institutions in the Implementation of Bicameral System in Indonesia

\section{CONCLUSIONS}

The bicameral system applied in Indonesia as a result of the constitutional amendment has resulted in the dispute of authority. The factors causing the disputes of state institutions include: in the constitutional system regulated in the 1945 Constitution after amendment, the mechanism of inter-state relations is horizontal, no longer vertical. Pattern relations between state institutions are checks and balances. The norms that determine the authority of subjects set forth in the 1945 Constitution, are not only related to the constitutional subjects commonly known so far in the execution of duties and functions of state institutions, but also related to the subject of broader authority. In the case of the implementation of the legislative function (the formation of law) there is also a dispute, especially related to the implementation of the authority of the Regional Representative Council of the Republic of Indonesia (DPD) and the House of Representatives of the Republic of Indonesia (DPR). Incorporate the veto in the process of forming the law as the authority of DPD.

\section{REFERENCES}

1. Rosyid Al Atok, 2015, The Concept of Establishment of Legislation, (Setara Press, Malang). 
2. A.V. Dicey, 1959, "Introduction to Study of the Law of the Constitution”, (London; Macmillan Education LTD).

3. Azhary, 1995, Indonesian Legal Country Indonesia Juridical Normative Analysis of its Elements, Cetakan Pertama, (UI Pres Jakarta).

4. Bagir Manan, 1992, The Basics of Indonesian Legislation, (Jakarta Indonesia Hill).

5. Dedy IsmatullahdanBeni Ahmad Saebani, 2009, the Constitutional Law: Reflections on State Life in the Republic of Indonesia, (Pustaka Setia, Bandung)

6. Elizabeth Walter..2008, Cambridge Advanced Leaner's Dictionary Third Edition Version 3.0.(Est Nyack, Cambridge University Press).

7. George H Sabine, 1961, A History of Political Theory, Third Edition (New York, Chicago, Loaded in JimlyAssiddiqie, 2009, the State of Law, Democracy and Business World, in Toward a Democratic Law State,( BIP, Jakarta).

8. Hans Kelsen, 1961, General Theory of Law and State, (Russel \& Russe, New York).

9. $\quad$ https://id.wikipedia.org/wiki/Sistem dua kamar

10. Jimly Assiddiqie; 2010, Development and Consolidation of State Institutions after the Reformation; (SinarGrafika, EdisiKedua, Cetakanpertama, Jakarta)

11. JimlyAssiddiqui2005, In the introduction to the Non-Federal Bicameral Book, Kelom pok DPD-RI.

12. Jimly Assiddiqui, 2006, State Inter-Authority Dispute Dispute, (Kon press, Jakarta).

13. M Daul Ali, M. Thahir Azhary, danHabibahDaud, the Islamic Discipline of Social and Political Law, (PT. Bulan Bintang, Jakarta).

14. M. Tahir Azhari, 2003, the State of Law: A Study of Its Principles Seen from the aspect of Islamic Laws Its Implementation in the Period of Medina and the Current Period. (Prenada Media, Jakarta).

15. Margaret M. Poloma, 2003, Contemporary Sociology, (Raja Grafindo Persada, cetakankelima, Jakarta).

16. Munir Fuadi, 2009, the Theory of Modern Law State, (Reka Aditama, Bandung).

17. Oemar Seno Aji, M. Tahir Azhari, in the State Law, 2003, A Study of Its Principles Seen from the aspect of Islamic Law Immigration in the Period of Medina and the Current Period. (Prenada Media, Jakarta).

18. Padmo Wahyono, M. TahirAzhari,2003, the State of Law: A Study of Its Principles Seen from the aspect of Islamic Law Implants in the Period of Medina and the Current.

19. Rahman, M. Taufik, 2011, Glossary of Social Theory, (Ibnu Sina Press, Bandung).

20. Rakyat Merdeka Online, DPD Gugat UU MD3 KeMahkamah Konstitusi, 8 September 2012.

21. Reni Dwi Purnomowati 2005, Implementation of Bicameral System in Indonesian Parliament, (Rajagrafindo Persada, Jakarta).

22. Rumusan Pasal 22D ayat (2) UUD Tahun 1945.

23. Sacipto Rahrjo, 2006, Legal studies, (PT Citra Aditya Bakti, Bandung).

24. SaldiIsra, Hak Veto Untuk DPD; dimuatdalam Harian Suara Karya, tanggal 22 JuniTahun 2006.

25. SaldiIsra, 2010, Shifting Legislative Functions: Strengthening the Parliamentary Legislative Model in Presidential Systems, (Rajagrafindo Persada, Jakarta). 
26. Sarja, 2016, the State Law In Theory and Practice. (Thafamedia, Yogyakarta).

27. Sudargo Gautama, 1983, Understanding of the State of Law, (Alumni, Bandung).

28. Valina Singka Subekti, 2008, Constructing the Transitional Constitution: The Flow of Interest and Thought in the Process of Change UUD 1945, (Rajawali Pers, Jakarta).

29. www.mahkamahkonstitusi.go.id, DPD Gugat UU MD3 dan UU P3 ke MK, 14 September 2012.

30. www.tempo.co.id, DPD Dituding Menginginkan Hak Veto, Kamis, 17 Mei 2007.

31. www.tempo.co.id, DPD Dituding Menginginkan Hak Veto, Kamis, 17 Mei 2007.

32. www.tempo.co.id, Marzuki: Usul Aman demen UUD Sebaiknya Dihentikan, 30 Agustus 2010.

33. www.hukumonline.com,Akhirnya DPD Gugat UU MD3,15 Agustus 2014. 
